\title{
In Situ Glucose Uptake and Glucokinase Activity of Pancreatic Islets in Diabetic and Obese Rodents
}

\author{
Yin Liang, * Susan Bonner-Weir, ${ }^{*}$ Ying-Jian Wu, ${ }^{\star}$ Carolyn D. Berdanier, ${ }^{8}$ Donna K. Berner," \\ Shimon Efrat, ' and Franz M. Matschinsky*\| \\ *Department of Biochemistry and Biophysics and "Diabetes Research Center, University of Pennsylvania, Philadelphia, Pennsylvania \\ 19104; ${ }^{\ddagger}$ Joslin Diabetes Center, Boston, Massachusetts 02215; ${ }^{\S}$ Department of Food and Nutrition, University of Georgia, \\ Athens, Georgia 30602; and 'Department of Molecular Pharmacology, Albert Einstein College of Medicine, Bronx, New York 10461
}

\begin{abstract}
The present study evaluated the involvement of glucose transport and phosphorylation in glucose-stimulated insulin release from pancreatic islets. Using quantitative histochemical techniques, we investigated basal islet glucose content, islet glucose uptake in situ during acute extreme experimental hyperglycemia, and islet glucokinase activity in several animal models of diabetes and obesity. The basal islet glucose content in anaesthetized diabetic or obese rodents was either the same or higher than that in their relevant controls. The rate of glucose uptake of islet tissue in these animals after an i.v. glucose injection was different. The $d b^{+} / d b^{+}$mouse and the obese Zucker rat exhibited significantly reduced islet glucose uptake rates. RIP-cHras transgenic mice, BHE/cdb rats and partially pancreatectomized rats showed normal islet glucose uptake rates. The activity of islet glucokinase was increased to a different degree related to the blood glucose level. All five animal models of diabetes or obesity exhibited either a delay or a reduction of insulin release in response to supra maximal glucose stimulation. Our results indicate that the impairment of glucose-induced insulin release in diabetes is not consistently associated with a reduction of islet glucose uptake nor a change of glucokinase activity. (J. Clin. Invest. 1994. 93:2473-2481.) Key words: diabetic animal • glucokinase • GLUT2 • insulin release • pancreatic islet
\end{abstract}

\section{Introduction}

Under physiological conditions, pancreatic $\beta$ cells sense the change of blood glucose level and adjust insulin output accordingly. The mechanism of glucose sensing by $\beta$ cells is, however, still unclear. There are two candidates for glucose sensors in pancreatic islets: the glucose transporter (GLUT2) ${ }^{1}$ and gluco-

Portions of this study were presented as abstract at the 53rd Annual Meeting of the American Diabetes Association, Las Vegas, Nevada, 12-15 June 1993.

Address correspondence to Dr. Franz M. Matschinsky, Diabetes Research Center, 501 Stemmler Hall, 36th \& Hamilton Walk, Philadelphia, PA 19104-6015.

Received for publication 20 August 1993 and in revised form 7 January 1994.

1. Abbreviations used in this paper: GLUT2, glucose transporter-2; PX, pancreatectomy; RIP-cHras, transgene composed of human [ $\mathrm{Val}^{12}$ ] Hras oncoprotein regulated by the rat insulin promoter.

J. Clin. Invest.

(c) The American Society for Clinical Investigation, Inc.

0021-9738/94/06/2473/09 \$2.00

Volume 93, June 1994, 2473-2481 kinase. GLUT2 is part of the $\beta$ cell plasma membrane $(1,2)$ and transports glucose into $\beta$ cells in a facilitative manner with a $K_{\mathrm{m}}$ of $15-20 \mathrm{mM}(3,4)$. Evidence favoring a role of GLUT2 in glucose sensing is substantial: $(a)$ In the obese, diabetic Zucker rat, GLUT2 expression is reduced at the mRNA and protein levels. The function of GLUT2 in islets is impaired. These defects correlate with insufficient insulin secretion in response to glucose (5). (b) An IgG preparation from patients with newly diagnosed insulin-dependent diabetes mellitus reduced the glucose uptake and decreased glucose-induced insulin release of normal rat islets $(6,7)$. GLUT2 has therefore been suggested as an essential element of the glucose sensor, and it has been proposed that a defect of GLUT-2 may play a crucial role in the pathogenesis of both insulin-dependent diabetes mellitus and non-insulin-dependent diabetes mellitus (8). Glucokinase, on the other hand, is the pacemaker of the glucose metabolism in islets $(9,10)$. The expression of glucokinase in the islet is controlled by a $\beta$ cell specific promoter (11), and its enzymatic activity is regulated by the blood glucose $(12,13)$. Recently $>20$ mutations of the glucokinase gene have been found in patients of mature onset diabetes of the young, who have impaired insulin secretion in response to glucose (14). Kinetic studies of recombinant mutant human glucokinase indicated a reduction of enzyme activity and an increase of the glucose $K_{\mathrm{m}}$ in many of the affected individuals (15). These findings demonstrate that glucokinase is a crucial determinant of glucose metabolism in pancreatic islets and support the view that this enzyme may serve as a glucose sensor (16).

The function of the islet glucose transporter and of glucokinase has been intensively studied using dispersed pancreatic $\beta$ cells or isolated islets. However, the procedure of islet isolation by collagenase digestion of the pancreas may influence islet function and could compromise the outcome of such studies, in particular the function of the glucose transporter, which is located in the $\beta$ cell membrane. In addition, one is unable to determine in these islets the basal glucose content, which is a reflection of the glucose transporter function in situ. To evaluate further the involvement of glucose transport and phosphorylation in the glucose-sensing mechanism, it is desirable to study basal islet glucose content, islet glucose uptake in situ during hyperglycemia, and to determine glucokinase activity by optimal techniques in normal and diabetic animals.

The quantitative histochemical techniques as developed by O. H. Lowry have been used since the 1950 s (17). These techniques permit the precise quantitation of enzymes, metabolites, and cofactors in microscopic structures sampled such that the in situ condition is virtually preserved. In its current version, which employs an oil well technique to handle volumes as small as $0.05 \mu l$ and the method of enzymatic cycling, femto- 
mol amounts of metabolites and cofactors, and picogram quantities of enzymes can be determined accurately. The application of the methodology has already benefited the study of glucose metabolism in pancreatic islets $(9,18,19)$.

We therefore used quantitative histochemical methods to investigate these aspects of glucose metabolism in islet samples dissected from freeze-dried cryostat sections of pancreas and to study glucose-induced insulin release in rodents. Both normal and five different models of diabetes or obesity were used. Our results indicate that the impairment of glucose-induced insulin release in these diabetic or obese animals is not consistently associated with a reduction of islet glucose uptake nor with a change in glucokinase activity. Defects in late steps of islet glucose metabolism, metabolic coupling or insulin secretion per se must be considered as possible causes for the desensitization of $\beta$ cells to glucose stimulation.

\section{Methods}

Animals. Five rodent models of diabetes or obesity and their relevant controls were chosen for this study: $(a)$ C57BL/KsJ- $d b^{+} / d b^{+}$mice (male and female, at $15 \mathrm{wk}$ of age and weighing 37-46 g) and C57BL/ KsJ mice (matched for age and sex, and weighing 20-31 g), were purchased from the Jackson Laboratory, Bar Harbor, ME. (b) Transgenic mice (male, at 8-9 wk of age and weighing 20-25 g) overexpressing the human [ $\mathrm{Val}^{12}$ ]HRAS oncoprotein in pancreatic $\beta$ cells under control of a rat insulin promoter (RIP-cHras) were used. C57BL/KsJ mice from the Jackson Laboratory were used as control for these animals. (c) BHE/cdb rats (cdb: Bureau of Home Economics, male and female, at $50 \mathrm{~d}$ or $12-16 \mathrm{mo}$ of age and weighing 276-570 g) were fed either ad lib. or with a diet containing $15 \%$ corn oil and $20.5 \%$ sucrose. Sprague Dawley rats (male and female, at 11-14 mo of age and weighing 260-562 g) were used as controls. (d) Partially pancreatectomized $(\mathrm{PX})$ and sham-pancreatectomized (sham-PX) rats (Sprague-Dawley male rats, about $100 \mathrm{~g}$ at time of surgery) were maintained for $9-10 \mathrm{wk}$ after surgery, before the actual study of islet glucose uptake. $(e)$ Obese $(\mathrm{fa} / \mathrm{fa}$ ) Zucker rats (male, at 4 mo of age and weighing 510-650 g) and lean Zucker rats (male, at 4 mo of age and weighing 370-430 g) were purchased from the Charles River Breeding Laboratories, Waltham, MA.

Animal surgery and sample preparation. Animals (except PX rats) were fasted overnight before the experiment. Nembutal $(100 \mathrm{mg} / \mathrm{kg}$ body weight) was injected i.p. to anaesthetize the animal. The jugular vein was cannulated for glucose and inulin injection, and the carotid artery was cannulated for the rapid collection of blood. After cannulation, heparin ( $100 \mathrm{USP} \mathrm{U} / \mathrm{kg}$ body weight) was injected. Inulin $(0.5$ $\mathrm{g} / \mathrm{kg}$ body weight), an extracellular marker, was injected $10 \mathrm{~min}$ before the glucose bolus. Glucose $(0.85 \mathrm{~g} / \mathrm{kg}$ body weight) was then injected within $5 \mathrm{~s}$. Animals were killed at 0,30 , or $60 \mathrm{~s}$ after glucose injection, and blood as well as pancreatic tissue samples were collected. The plasma was kept at $-20^{\circ} \mathrm{C}$ for inulin, glucose and insulin determinations. The pancreas was quickly frozen in Freon- 12 cooled to $-150^{\circ} \mathrm{C}$ by liquid nitrogen and stored at $-80^{\circ} \mathrm{C}$ for measuring inulin, glucose and insulin content in islet, as well as islet glucokinase. Sprague-Dawley rats, BHE rats (fed a high fat diet) and Zucker rats (lean and $f a / f a$ ) were also used for an i.v. glucose tolerance test. Glucose $(0.85 \mathrm{~g} / \mathrm{kg}$ body weight) was injected into the jugular vein within $5 \mathrm{~s}$. Blood was collected in $0.3 \mathrm{ml}$ samples at $0,1,2,5,10,15,30,60,90$, and $120 \mathrm{~min}$ after glucose injection and plasma samples were kept at $-20^{\circ} \mathrm{C}$ until assayed for glucose and insulin.

Determination of plasma inulin, glucose and insulin concentrations. The inulin and glucose concentrations in the plasma were measured with an NADP coupled fluorometric assay (20). Plasma insulin was determined by radioimmunoassay as described before (21).

Morphologic study. Pancreatic tissue of the BHE rats on the normal diet was immersed in paraformaldehyde/lysine/periodate fixative and then embedded in paraffin. Sections were immunoperoxidase stained for the non- $\beta$ cell islet hormones to show the boundaries of the islets (22).

Preparation of islet sample for quantitative histochemical analysis. Sections of the pancreas were cut $20 \mu \mathrm{m}$ thick at $-20^{\circ} \mathrm{C}$ in a cryostat, freeze dried overnight at $-35^{\circ} \mathrm{C}$, and then stored under vacuum at $-20^{\circ} \mathrm{C}$. Islets were dissected from pancreatic sections with the aid of a stereo microscope at low magnification. The weights of the specimens were obtained with the quartz fiber fishpole balance (23).

Determination of islet insulin, glucose, and inulin contents. The islet insulin content was determined by radioimmunoassay. The glucose and inulin content in the pancreatic islet tissue were measured by a fluorometric oil well method combined with enzymatic cycling of NADP $(18,20)$. For islet glucose content determination, islet samples were first suspended in $0.1 \mu \mathrm{l}$ of $0.015 \mathrm{~N} \mathrm{HCl}$ under mineral oil and incubated at $60^{\circ} \mathrm{C}$ for $10 \mathrm{~min}$. The glucose in the sample was measured enzymatically with hexokinase and glucose-6-phosphate dehydrogenase and followed by a 500 -fold amplification by enzyme cycling. For the inulin determination, the islet sample was suspended in $0.05 \mu \mathrm{l}$ of $0.1 \mathrm{~N} \mathrm{NaOH}$ and heated at $105^{\circ} \mathrm{C}$ for $25 \mathrm{~min}$, then $0.1 \mu \mathrm{l}$ of $0.1 \mathrm{~N} \mathrm{HCl}$ was added followed by heating at $105^{\circ} \mathrm{C}$ for $25 \mathrm{~min}$. Fructose, resulting from hydrolysis of inulin, was determined fluorometrically with an NADP-dependent assay using hexokinase, phosphoglucose isomerase and glucose-6-phosphate dehydrogenase followed by a 3,000-fold amplification through enzyme cycling in order to achieve higher sensitivity. Standard curves of NADPH (4-20 pmol), glucose (4-20 pmol), and inulin (20-100 fmol) were used in each experiment for calculation. Samples from nine individual islets were assayed and averaged for each animal. The islet glucose and inulin contents were then used to calculate the islet total glucose space, extracellular space and intracellular glucose space using the following formulas:

Islet glucose content ( $\mathrm{mmol} / \mathrm{kg}$ dry weight)

Plasma glucose concentration (mmol/liter)

$=$ total islet glucose space (liter $/ \mathrm{kg}$ dry weight)

Islet inulin content ( $\mathrm{mmol} / \mathrm{kg}$ dry weight)

Plasma inulin concentration ( $\mathrm{mmol} /$ liter)

$=$ islet extracellular space (liter $/ \mathrm{kg}$ dry weight)

Total islet glucose space - islet extracellular space

(liter $/ \mathrm{kg}$ dry weight) (liter $/ \mathrm{kg}$ dry weight)

$=$ intracellular glucose space

(liter/kg dry weight)

Islet glucokinase determination. Glucokinase activity in islet tissue was determined using a radiometric micromethod (24). Approximately 3-4 $\mu \mathrm{g}$ of islet tissue, pooled from 30-40 individually dissected islet specimens, was suspended in $2 \mu 1$ of sample buffer containing 50 $\mathrm{mM}$ Hepes, $500 \mathrm{mM} \mathrm{KCl}, 8 \mathrm{mM} \mathrm{MgCl}_{2}, 10 \mathrm{mM}$ dithiothreitol, $10 \mathrm{mM}$ glucose-6-phosphate, and $0.1 \%$ bovine serum albumin. The islet preparation was then distributed in $0.1-\mu$ l aliquots into 12 miniwells filled with mineral oil and $0.1 \mu \mathrm{l}$ of buffer containing $0.5 \mu \mathrm{Ci} \mathrm{D}-\left[2-{ }^{3} \mathrm{H}(\mathrm{N})\right]-$ glucose with different concentrations of unlabeled glucose (0.5-21.2 $\mathrm{mM}$ ) was added to each sample in the oil well. The reaction was initiated by adding $0.03 \mu \mathrm{l}$ of $50 \mathrm{mM}$ ATP. Incubation was for $60 \mathrm{~min}$ at $22^{\circ} \mathrm{C}$. The reaction was terminated by the addition of $2 \mu \mathrm{l} 1.5 \mathrm{M}$ glucose containing $110 \mathrm{mM}$ EDTA. The ${ }^{3} \mathrm{H}_{2} \mathrm{O}$ was liberated from the product $\mathrm{D}-\left[2-{ }^{3} \mathrm{H}(\mathrm{N})\right]$ glucose 6-phosphate using phosphoglucose isomerase and was separated from the substrate $D-\left[2-{ }^{3} \mathrm{H}(\mathrm{N})\right]$ glucose by an overnight diffusion step at $30^{\circ} \mathrm{C}$. Tritiated water (DuPont Co., Billerica, MA) and $\mathrm{D}-\left[2-{ }^{3} \mathrm{H}(\mathrm{N})\right]$ glucose 6-phosphate standards (prepared according to the method of Bedoya et al. [24]) were used to calculate the conversion and diffusion efficiency. The kinetic constants of glucokinase were analyzed by Hanes-Woolf plots. Glucokinase velocities at glucose concentrations between 1.4 and $21.2 \mathrm{mM}$ were corrected for the hexokinase component by subtracting the activity at 
$0.5 \mathrm{mM}$ glucose. The enzyme activities were corrected for a temperature of $37^{\circ} \mathrm{C}$ using a $Q_{10}$ of $2(25)$.

\section{Results}

Basal plasma glucose, basal insulin level, and glucose-induced insulin release. Animals were fasted overnight, except for the PX and sham-PX rats, and plasma glucose as well as basal insulin levels under anesthesia were determined in five rodent models of diabetes or obesity and their controls (Table I and Fig. 1). The RIP-cHras transgenic mice and the BHE/cdb rats (12-14 mo of age, with normal diet) showed normal plasma glucose levels when compared with the C57BL/KsJ mice or the Sprague-Dawley rat, as well as with the young BHE/cdb rats ( $50 \mathrm{~d}$ of age), respectively. The $d b^{+} / d b^{+}$mice, BHE/cdb rats on a high fat diet, obese Zucker, and PX rats were hyperglycemic, compared with their relevant controls. The fasting plasma insulin level in the BHE/cdb rats on a high fat diet and in the obese Zucker rats were clearly elevated. After injection of a large glucose challenge, the plasma glucose level increased dramatically in all the animals but the response of plasma insulin level varied greatly. In control groups the plasma insulin increased two- to threefold at $30 \mathrm{~s}$ and reached even higher level at $60 \mathrm{~s}$ after glucose injection. RIP-cHras and $\mathrm{db}^{+} / d b^{+}$mice, BHE, obese Zucker, and PX rats failed to show an increase of plasma insulin when plasma glucose increased. The BHE/cdb rat fed a high fat diet showed a significant increase of insulin release, however, this insulin release was delayed by $30 \mathrm{~s}$. The results of i.v. glucose tolerance test in the BHE/cdb rats fed a high fat diet and in obese Zucker rats showed abnormal glucose tolerance when compared to the respective controls (Fig. 1). The plasma glucose remained at an excessively high level of $>30 \mathrm{mM}$ for $120 \mathrm{~min}$ after the glucose bolus, while in the controls plasma glucose returned to basal level. The first phase of glucose-induced insulin release in BHE/cdb rats ( on a high fat diet) and obese Zucker rats reached higher hormone levels than in their controls $(P<0.05)$, but the second phase response was similar in experimental groups and controls.

Basal glucose content and in situ glucose uptake of islet tissue after glucose i.v. injection. Quantitative histochemical techniques were used to determine the basal islet glucose content and to assess the capacity of islet cell glucose transport at near-maximal substrate load. The result for each animal represents the average of nine different islet samples. The standard errors were $<10 \%$ for glucose determinations and $<20 \%$ for inulin determinations.

The total basal islet glucose contents in normal animals ranged from 27 to $35 \mathrm{mmol} / \mathrm{kg}$ dry tissue (Tables II and III). These values extrapolated to a total islet glucose space of 2.7 to 3.9 liter $/ \mathrm{kg}$ dry tissue. The values of total islet glucose space indicate that the glucose concentration in islet tissue is equal to the plasma glucose concentration. This calculation is based on an islet water space of $0.75 \mathrm{liter} / \mathrm{kg}$ wet islet tissue (26). In different animal models of diabetes or obesity, basal total islet glucose contents were higher than in controls, except in the case of RIP-cHras transgenic mice. The values of total glucose space in all the animal models of diabetes or obesity ranged from 2.4 to 3.6 liter $/ \mathrm{kg}$ dry tissue, which was very similar to results in their relevant control groups. The values for islet extracellular spaces ranged from 0.55 to $0.92 \mathrm{liter} / \mathrm{kg}$ dry weight in the control groups and from 0.55 to 0.85 liter $/ \mathrm{kg}$ dry weight in most diabetic and obese animals, except in the BHE/ $\mathrm{cdb}$ rat which manifested a much higher extracellular space. The intracellular glucose space of islets in the controls ranged from 2.1 to 3.3 liter $/ \mathrm{kg}$ dry weight. In the RIP-cHras transgenic mouse, PX and obese Zucker rats, the intracellular glucose space ranged from 1.9 to 2.8 liter/ kg dry weight, not signifcantly lower than the values in their controls. However, the intracellular glucose space in the $d b^{+} / d b^{+}$mice and in the $\mathrm{BHE} / \mathrm{cdb}$ rat was clearly lower than that of their controls. The

Table I. Plasma Glucose and Insulin Levels in Normal, Diabetic, or Obese Rodents under Basal Condition and after i.v. Loading

\begin{tabular}{|c|c|c|c|c|c|c|}
\hline \multirow[b]{3}{*}{ Rodents } & \multicolumn{3}{|c|}{ Plasma glucose (mM) } & \multicolumn{3}{|c|}{ Plasma insulin (ng/ml) } \\
\hline & \multirow{2}{*}{$\begin{array}{l}\text { Basal } \\
\text { condition } \\
0 \text { time }\end{array}$} & \multicolumn{2}{|c|}{ After glucose injection } & \multirow{2}{*}{$\begin{array}{l}\text { Basal } \\
\text { condition } \\
0 \text { time }\end{array}$} & \multicolumn{2}{|c|}{ After glucose injection } \\
\hline & & $30 \mathrm{~s}$ & $60 \mathrm{~s}$ & & $30 \mathrm{~s}$ & $60 \mathrm{~s}$ \\
\hline C57BL/KsJ mouse (controls, $n=12$ ) & $10.07 \pm 0.74$ & $45.37 \pm 3.53^{\ddagger}$ & $37.63 \pm 2.48^{\ddagger}$ & $2.08 \pm 0.60^{\S}$ & $4.86 \pm 1.82^{\S}$ & $4.96 \pm 0.93^{* \S}$ \\
\hline$d b^{+} / d b^{+}$mouse $(n=6)$ & $46.92 \pm 4.15^{* *}$ & $119.50 \pm 15.97^{\ddagger}$ & $96.52 \pm 9.01^{\ddagger}$ & $3.63 \pm 0.40^{\prime \prime}$ & $5.81 \pm 1.84^{\prime \prime}$ & $4.26 \pm 1.08^{\prime \prime}$ \\
\hline RIP-cHras mouse $(n=4)$ & $7.72 \pm 0.75$ & ND & $38.33 \pm 1.37^{\ddagger}$ & $1.09 \pm 0.34$ & ND & $0.62 \pm 0.24$ \\
\hline BHE rat ( $50 \mathrm{~d}$ of age, $n=6)$ & $6.64 \pm 0.44$ & $24.38 \pm 1.16^{\ddagger}$ & $27.79 \pm 0.57^{\ddagger}$ & $1.23 \pm 0.15$ & $5.20 \pm 0.59^{\ddagger}$ & $5.67 \pm 1.24^{*}$ \\
\hline \multicolumn{7}{|l|}{ Sprague-Dawley rat (controls, } \\
\hline $11-14$ mo of age, $n=4)$ & $9.19 \pm 1.27$ & $100.25 \pm 14.38^{\ddagger \ddagger}$ & $69.16 \pm 4.25^{\ddagger \ddagger}$ & $1.60 \pm 0.51$ & $4.38 \pm 2.2$ & $6.43 \pm 0.71^{\ddagger}$ \\
\hline BHE rat $(n=4)$ & $10.69 \pm 0.91$ & $47.76 \pm 5.27^{\ddagger}$ & $35.19 \pm 2.32^{\ddagger}$ & $2.89 \pm 1.44$ & $2.69 \pm 1.32$ & $4.33 \pm 0.64$ \\
\hline \multicolumn{7}{|l|}{ BHE rat on fat diet (12-16 mo } \\
\hline of age, $n=6$ ) & $17.17 \pm 1.20^{* *}$ & $78.28 \pm 2.19^{* *}$ & $61.37 \pm 4.25^{\ddagger}$ & $7.96 \pm 0.83^{* *}$ & $7.58 \pm 3.67$ & $13.40 \pm 2.13^{*}$ \\
\hline Sham-PX rat (controls, $n=6$ ) & $9.00 \pm 1.27$ & ND & $33.84 \pm 2.21^{\ddagger}$ & $3.92 \pm 1.05$ & ND & $9.11 \pm 1.20^{\ddagger}$ \\
\hline PX rat $(n=7)$ & $20.30 \pm 2.60^{\prime}$ & ND & $39.99 \pm 4.17^{\ddagger}$ & $1.21 \pm 0.19$ & ND & $3.01 \pm 0.99$ \\
\hline Lean Zucker rat (controls, $n=6$ ) & $10.24 \pm 0.76$ & $54.95 \pm 1.80^{\ddagger}$ & $51.97 \pm 1.81^{\ddagger}$ & $4.53 \pm 0.75$ & $12.61 \pm 2.02^{\ddagger}$ & $18.36 \pm 1.79^{\ddagger}$ \\
\hline Obese Zucker rat $(n=6)$ & $14.82 \pm 1.34^{\prime}$ & $67.83 \pm 4.43^{\ddagger}$ & $66.50 \pm 5.75^{\ddagger}$ & $38.65 \pm 6.93^{* *}$ & $30.03 \pm 6.43$ & $49.79 \pm 7.85$ \\
\hline
\end{tabular}

Plasma glucose and insulin samples were collected from individual animals killed at 0,30 , and $60 \mathrm{~s} . \quad * P<0.05$, compared with 0 time point in the same group; ${ }^{\ddagger} P<0.01$ compared with 0 time point in the same group. ${ }^{8} n=8 ; " ~ n=3$. ' $P<0.05$ compared with control group; ${ }^{* *} P$ $<0.01$ compared with control group at 0 time point (both for glucose and insulin data). \# The atypical high plasma glucose was the result of an inadvertently large i.v. glucose load (compare with lean Zucker rats). 

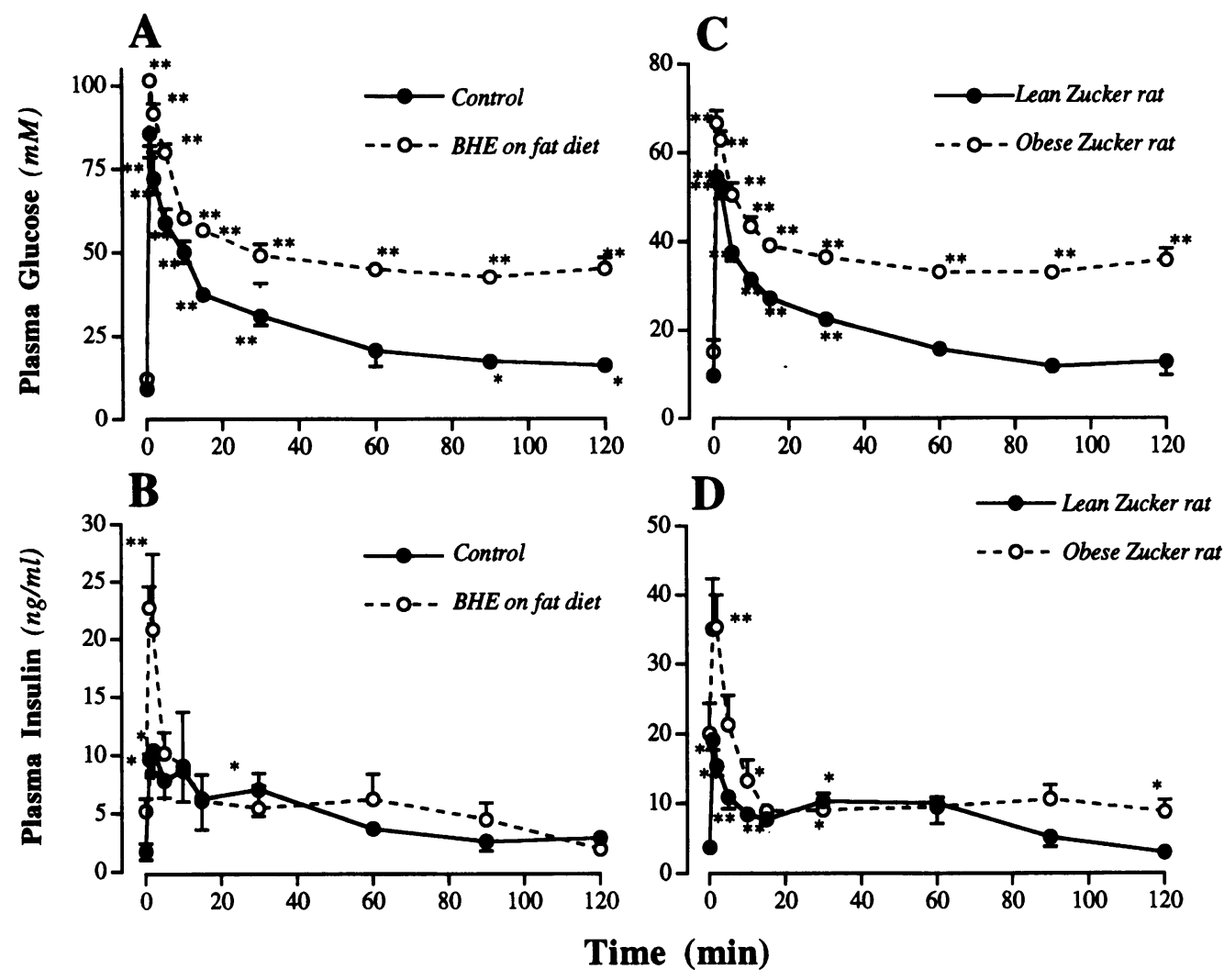

Figure 1. Plasma glucose and insulin levels in normal Sprague-Dawley rats $(n=5)$, BHE rats on a high fat diet $(n=2)$, lean Zucker rats ( $n$ $=6)$, and obese Zucker rats $(n=6)$ during an i.v. glucose tolerance test. ${ }^{*} P<0.05,{ }^{* *} P$ $<0.01$ compared with the value at basal conditions in the same group of animals.

morphological examination of the $\mathrm{BHE} / \mathrm{cdb}$ rat islet tissue revealed substantial fibrosis. Fig. 2 provides samples of apparently normal and fibrotic islets of the same pancreas of a male $\mathrm{BHE} / \mathrm{cdb}$ rat. The extensive fibrosis might explain the increase of the extracellular space associated with a decreased intracellular glucose space. At $50 \mathrm{~d}$ of age, the BHE/cdb rat has a normal islet extracellular and intracellular space (Table III), and normal islet morphology (data not shown). In the case of the $d b^{+} / d b^{+}$mouse, the extracellular space was comparable to controls. The apparent decrease of the intracellular glucose space might therefore indicate loss of $\beta$ cell mass, as would be expected at this age of the $d b^{+} / d b^{+}$mouse.
After glucose injection, the total islet glucose content in all animals was increased significantly at $30 \mathrm{~s}$. In control animals, the total islet glucose space was reduced to $\sim 75 \%$ of that under the basal condition, indicating that equalization of intracellular and extracellular glucose had not been complete. The intracellular and extracellular glucose were approximately equalized at $60 \mathrm{~s}$ after glucose injection in the control group, except in the C57BL/KsJ mice in which the intracellular glucose space reached $79 \%$ of that in the basal condition. In diabetic or obese animals, apparent glucose uptake rates varied widely. In the $d b^{+} / d b^{+}$mice, glucose uptake was much slower than that in the control. Even after $60 \mathrm{~s}$, the intracellular glucose space was

Table II. Basal Glucose Content and Glucose Uptake of Pancreatic Islets after Glucose Challenge in Normal and Diabetic Mice

\begin{tabular}{|c|c|c|c|c|}
\hline Rodents & $\begin{array}{l}\text { Total glucose } \\
\text { content }\end{array}$ & $\begin{array}{l}\text { Total glucose } \\
\text { space }\end{array}$ & $\begin{array}{l}\text { Extracellular } \\
\text { inulin space }\end{array}$ & $\begin{array}{l}\text { Intracellular } \\
\text { glucose space }\end{array}$ \\
\hline & $\mathrm{mmol} / \mathrm{kg}$ dry tissue & & liter/kg dry tissue & \\
\hline \multicolumn{5}{|c|}{ C57BL/KsJ mouse (controls, $n=6$ ) } \\
\hline Basal condition & $34.15 \pm 2.55$ & $3.48 \pm 0.24$ & $0.63 \pm 0.08$ & $2.85 \pm 0.22$ \\
\hline $30 \mathrm{~s}$ after $\mathrm{G}$ injection & $137.30 \pm 13.67^{\ddagger}$ & $2.91 \pm 0.19$ & $0.91 \pm 0.05^{*}$ & $2.00 \pm 0.21^{*}$ \\
\hline $60 \mathrm{~s}$ after $\mathrm{G}$ injection & $109.12 \pm 6.65^{\ddagger}$ & $2.94 \pm 0.14$ & $0.70 \pm 0.07$ & $2.24 \pm 0.14^{*}$ \\
\hline \multicolumn{5}{|l|}{$d b^{+} / d b^{+}$mouse $(n=6)$} \\
\hline Basal condition & $111.85 \pm 9.45^{\|}$ & $2.48 \pm 0.32^{8}$ & $0.85 \pm 0.11$ & $1.63 \pm 0.31^{11}$ \\
\hline $30 \mathrm{~s}$ after $\mathrm{G}$ injection & $141.13 \pm 11.60$ & $1.37 \pm 0.12^{\ddagger}$ & $0.87 \pm 0.07$ & $0.50 \pm 0.10^{\ddagger}$ \\
\hline $60 \mathrm{~s}$ after $\mathrm{G}$ injection & $135.27 \pm 7.38$ & $1.38 \pm 0.15^{\ddagger}$ & $0.61 \pm 0.07$ & $0.77 \pm 0.15^{*}$ \\
\hline \multicolumn{5}{|l|}{ H-ras transg.mouse $(n=4)$} \\
\hline Basal condition & $21.53 \pm 0.75^{\S}$ & $2.78 \pm 0.75$ & $0.73 \pm 0.19$ & $2.05 \pm 0.18$ \\
\hline $60 \mathrm{~s}$ after $\mathrm{G}$ injection & $88.99 \pm 12.93^{\ddagger}$ & $2.36 \pm 0.42$ & $0.76 \pm 0.14$ & $1.60 \pm 0.51$ \\
\hline
\end{tabular}

${ }^{*} P<0.05$, compared with basal condition in the same group; ${ }^{\ddagger} P<0.01$ compared with basal condition in the same group. ${ }^{\S} P<0.05$ compared with control group at basal condition; " $P<0.01$ compared with control group at basal condition. 
Table III. Basal Glucose Content and Glucose Uptake of Pancreatic Islets after Glucose Challenge in Normal and Diabetic or Obese Rats

\begin{tabular}{|c|c|c|c|c|}
\hline Rodents & $\begin{array}{l}\text { Total glucose } \\
\text { content }\end{array}$ & $\begin{array}{l}\text { Total glucose } \\
\text { space }\end{array}$ & $\begin{array}{l}\text { Extracellular } \\
\text { inulin space }\end{array}$ & $\begin{array}{l}\text { Intracellular } \\
\text { glucose space }\end{array}$ \\
\hline & $\mathrm{mmol} / \mathrm{kg}$ dry tissue & & liter/kg dry tissue & \\
\hline \multicolumn{5}{|c|}{ BHE rat ( $50 \mathrm{~d}$ of age, $n=6$ ) } \\
\hline Basal condition & $23.99 \pm 0.86$ & $3.81 \pm 0.17$ & $1.03 \pm 0.02$ & $2.78 \pm 0.17$ \\
\hline $30 \mathrm{~s}$ after $\mathrm{G}$ injection & $95.50 \pm 2.70^{ \pm 11}$ & $3.94 \pm 0.15$ & $1.72 \pm 0.30$ & $1.01 \pm 0.44$ \\
\hline $60 \mathrm{~s}$ after $\mathrm{G}$ injection & $90.17 \pm 12.90^{* *}$ & $2.58 \pm 0.35$ & $1.97 \pm 0.31$ & $0.84 \pm 0.37$ \\
\hline $60 \mathrm{~s}$ after $\mathrm{G}$ injection & $98.50 \pm 9.46^{\ddagger 11}$ & $3.53 \pm 0.31$ & $0.94 \pm 0.11$ & $2.62 \pm 0.34$ \\
\hline \multicolumn{5}{|c|}{$\begin{array}{l}\text { Sprague-Dawley rat (controls, } 11-14 \text { mo } \\
\text { of age, } n=4 \text { ) }\end{array}$} \\
\hline Basal condition & $31.45 \pm 4.53$ & $3.48 \pm 0.33$ & $0.92 \pm 0.08$ & $2.56 \pm 0.31$ \\
\hline $30 \mathrm{~s}$ after $\mathrm{G}$ injection & $301.76 \pm 45.18^{ \pm 11}$ & $3.12 \pm 0.42$ & $1.62 \pm 0.26^{* 11}$ & $1.50 \pm 0.39$ \\
\hline $60 \mathrm{~s}$ after $\mathrm{G}$ injection & $293.60 \pm 17.56^{\ddagger 11}$ & $4.25 \pm 0.13$ & $1.23 \pm 0.19^{* 11}$ & $3.02 \pm 0.10$ \\
\hline \multicolumn{5}{|c|}{ BHE rat (12-14 mo of age, $n=4)$} \\
\hline Basal condition & $31.29 \pm 9.25$ & $2.94 \pm 0.70$ & $1.88 \pm 0.30^{\S}$ & $1.06 \pm 0.40^{\S}$ \\
\hline $30 \mathrm{~s}$ after $\mathrm{G}$ injection & $129.98 \pm 9.95^{\ddagger}$ & $2.73 \pm 0.35$ & $1.72 \pm 0.30$ & $1.01 \pm 0.44$ \\
\hline $60 \mathrm{~s}$ after $\mathrm{G}$ injection & $90.17 \pm 12.90^{* *}$ & $2.58 \pm 0.35$ & $1.97 \pm 0.31$ & $0.84 \pm 0.37$ \\
\hline \multicolumn{5}{|c|}{$\begin{array}{l}\text { BHE rat on fat diet (12-14 mo } \\
\quad \text { of age, } n=6)\end{array}$} \\
\hline Basal condition & $45.45 \pm 5.27$ & $2.63 \pm 0.17$ & $1.03 \pm 0.17$ & $1.60 \pm 0.34$ \\
\hline $30 \mathrm{~s}$ after $\mathrm{G}$ injection & $233.15 \pm 16.73^{\ddagger}$ & $2.98 \pm 0.20$ & $1.76 \pm 0.20^{*}$ & $1.02 \pm 0.21$ \\
\hline $60 \mathrm{~s}$ after $\mathrm{G}$ injection & $175.35 \pm 27.32^{\ddagger}$ & $2.82 \pm 0.34$ & $1.47 \pm 0.26$ & $1.35 \pm 0.17$ \\
\hline \multicolumn{5}{|l|}{ Sham-PX rat $(n=6)$} \\
\hline Basal condition & $34.74 \pm 5.87$ & $3.81 \pm 0.52$ & $0.51 \pm 0.09$ & $3.30 \pm 0.47$ \\
\hline $60 \mathrm{~s}$ after $\mathrm{G}$ injection & $122.44 \pm 9.69^{\ddagger}$ & $3.63 \pm 0.20$ & $0.76 \pm 0.13$ & $2.87 \pm 0.21$ \\
\hline \multicolumn{5}{|l|}{ Px rat $(n=7)$} \\
\hline Basal condition & $71.59 \pm 9.86$ & $3.63 \pm 0.36$ & $0.80 \pm 0.20$ & $2.83 \pm 0.46$ \\
\hline $60 \mathrm{~s}$ after $\mathrm{G}$ injection & $126.59 \pm 8.65^{\ddagger}$ & $3.25 \pm 0.21$ & $0.80 \pm 0.20$ & $2.45 \pm 0.31$ \\
\hline \multicolumn{5}{|l|}{ Lean Zucker rat $(n=6)$} \\
\hline Basal condition & $27.46 \pm 1.78^{8}$ & $2.72 \pm 0.20$ & $0.61 \pm 0.07$ & $2.11 \pm 0.16$ \\
\hline $30 \mathrm{~s}$ after $\mathrm{G}$ injection & $154.28 \pm 10.07^{\ddagger}$ & $2.80 \pm 0.15$ & $0.72 \pm 0.08$ & $2.08 \pm 0.12$ \\
\hline $60 \mathrm{~s}$ after $\mathrm{G}$ injection & $146.05 \pm 7.39^{\ddagger}$ & $2.73 \pm 0.17$ & $0.86 \pm 0.09$ & $1.87 \pm 0.17$ \\
\hline \multicolumn{5}{|l|}{ Obese Zucker rat $(n=6)$} \\
\hline Basal condition & $36.29 \pm 4.10$ & $2.43 \pm 0.09$ & $0.55 \pm 0.05$ & $1.88 \pm 0.09$ \\
\hline $30 \mathrm{~s}$ after $\mathrm{G}$ injection & $132.97 \pm 8.09^{\ddagger}$ & $1.92 \pm 0.16$ & $0.75 \pm 0.07$ & $1.17 \pm 0.14^{\ddagger}$ \\
\hline $60 \mathrm{~s}$ after $\mathrm{G}$ injection & $135.89 \pm 7.22^{\ddagger}$ & $2.10 \pm 0.19$ & $0.71 \pm 0.07$ & $1.39 \pm 0.18^{*}$ \\
\hline
\end{tabular}

Pancreatic samples were collected at 0 time to determine the basal islet total glucose content, extracellular and intracellular space. ${ }^{*} P<0.05$, compared with basal condition in the same group; ${ }^{\ddagger} P<0.01$ compared with basal condition in the same group. ${ }^{\S} P<0.05$ compared with control group at basal condition. "The strikingly high total glucose contents and the expanded extracellular space values after glucose loading were a manipulation of an inadvertently high dose of i.v. glucose (also Table I).

still $<50 \%$ of that at the basal condition, indicating that the glucose uptake rate of these islet cells was much slower than that in controls. In the obese Zucker rat, the glucose uptake rate was also decreased, yet $60 \mathrm{~s}$ after glucose injection, the intracellular glucose space had reached $74 \%$ of that at the basal condition. However, in RIP-cHras mice, BHE/cdb rats (fed either a stock or a high fat diet) and PX rats, equalization between extracellular and intracellular glucose concentrations in the islets was nearly achieved at $60 \mathrm{~s}$.

Glucokinase activity and insulin content in pancreatic islets. The islet glucokinase activity in the $d b^{+} / d b^{+}$mice, the BHE/ cdb rat (fed either a stock or a high fat diet) and the obese Zucker rat, as well as their control groups was measured with a radiometric oil well method. The supernatant of rat liver homogenate was used as a biological standard. The $V_{\max }$ value of liver glucokinase was $60.97 \pm 3.28 \mathrm{~mol} / \mathrm{kg}$ DNA per $\mathrm{h}$ and the glucose $K_{\mathrm{m}}$ was $13.10 \pm 1.98 \mathrm{mM}$, comparable to results previously obtained in this laboratory (24). The glucose $K_{\mathrm{m}}$ of islet glucokinase in all the animals ranged from 8 to $19 \mathrm{mM}$ ( Table IV). The $V_{\max }$ of glucokinase in control animals ranged from 103 to $142 \mathrm{mmol} / \mathrm{kg}$ dry tissue per $\mathrm{h}$, which is equivalent to 5.15 to $7.10 \mathrm{~mol} / \mathrm{kg}$ DNA per $\mathrm{h}$ using a factor of $20 \mathrm{ng}$ DNA/ $\mu \mathrm{g}$ dry islet tissue (27). These values are similar to previous results obtained with a fluorometric method in rat islet isolated by a collagenase procedure $(13,28)$. Since the $\beta$ cell mass may be reduced in these diabetic animals as indicated by the reduced intracellular glucose space, the glucokinase $V_{\max }$ was also expressed on the basis of intracellular glucose space. On that basis, islet glucokinase activities were substantially increased. The glucose $K_{\mathrm{m}}$ of islet glucokinase in these diabetic or obese rodents were not significantly different from that in their controls, except the $f a / f a$ Zucker rats. Islet glucose metabolism in 


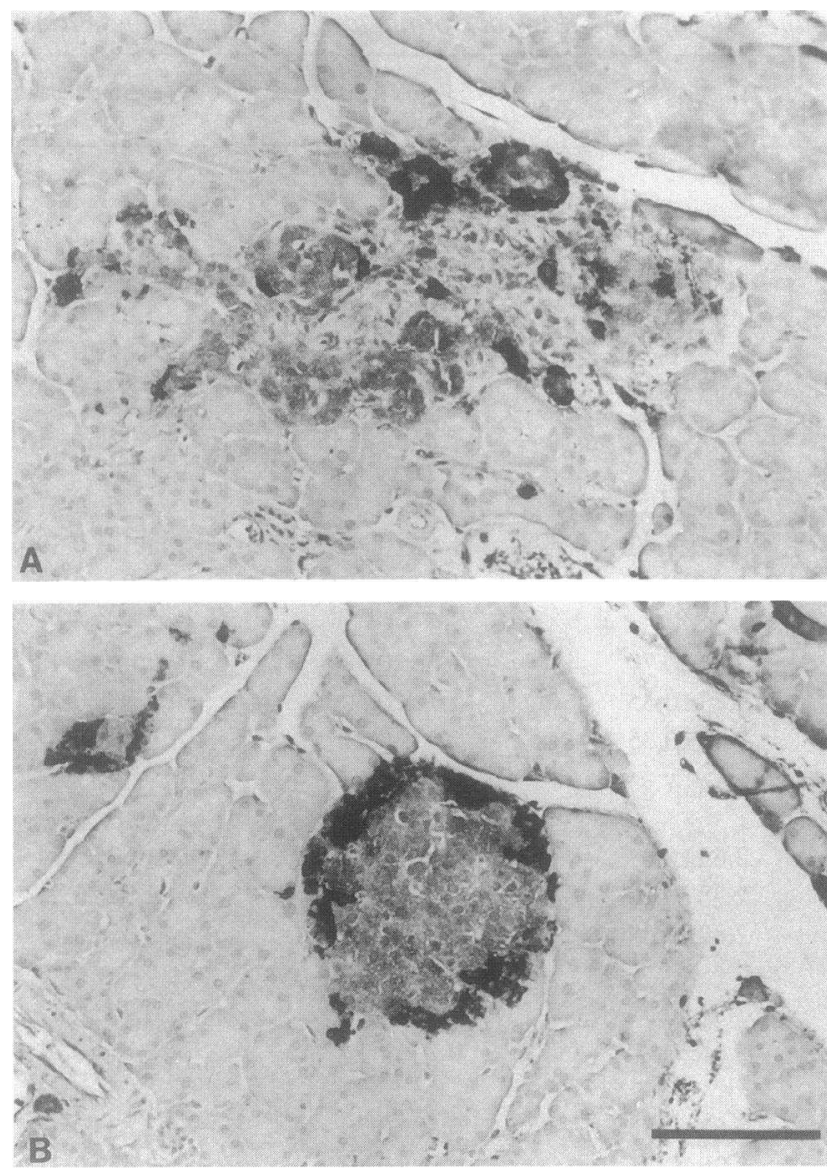

Figure 2. BHE rats show abnormal islet morphology in most of islets of old male animals. $(A)$ Abnormal, fibrotic islet with distortion of mantle (black staining) of non- $\beta$-endocrine cells and core of $\beta$ cells (gray) compared with $(B)$ normal islet from same animal. Paraffin section immunostained for non- $\beta$-islet hormones, counterstained with hematoxylin. Bar, $100 \mu \mathrm{m}$.

the obese Zucker rat needs to be intensively studied to clarify whether this increased glucose $K_{\mathrm{m}}$ has pathological significance for the impairment of glucose-induced insulin release in these animals.

The insulin contents in BHE/cdb rats and in obese Zucker rats were comparable to control values, while the insulin content in the $d b^{+} / d b^{+}$mice was only $5-10 \%$ of that in the control.
Relationship of in situ islet glucose uptake and glucose-induced insulin release. The relationship of in situ islet glucose uptake and glucose induced insulin release was explored in diabetic or obese animals and their controls (Fig. 3). The intracellular glucose space and glucose-induced insulin release at 30 and $60 \mathrm{~s}$ after glucose injection were expressed in relative terms as compared to the relevant values at the basal condition (defined as 100). The control bar in this figure reflects the mean of five different control groups. In control animals, the plasma insulin levels increased 2.5 fold at $30 \mathrm{~s}$ after glucose injection, and almost fourfold at $60 \mathrm{~s}$. However, in diabetic and obese animals, the glucose-induced insulin release was delayed or greatly reduced compared with that of their controls. Glucose uptake was impaired only in $d b^{+} / d b^{+}$mice and obese Zucker rats. Thus there was no absolute association between glucose uptake and glucose-induced insulin release.

\section{Discussion}

The relationship of islet in situ glucose uptake, glucokinase activity, and glucose-induced insulin release was investigated in five animal models of diabetes or obesity using quantitative histochemical methods. The unique potential of the present approach and the implications of present results for our understanding of the pathogenic process leading to diabetes mellitus in these animals are discussed.

Advantages and limitations of quantitative histochemistry for the study of pancreatic islet glucose metabolism

The pancreatic islet glucose transporter and glucokinase have emerged as important topics in studying the pathogenesis of diabetes. A direct assessment of the involvement of islet glucose transport and glucokinase in rodent models of diabetes and obesity with quantitative histochemical methods, which allows in situ measurements, appeared therefore highly desirable. The rapid freezing method for tissue sampling and the free-hand dissection of pure pancreatic islet specimens from freeze-dried tissue sections, as employed here, avoid artifacts that could be introduced by the lengthy procedure of collagenase isolation of pancreatic islets, which usually precedes most physiological or biochemical investigation. Thus, the quantitative histochemical method offers an independent reexamination of the issue. The determination of the total islet glucose space, of the inulin or extracellular space and of the intracellular glucose space under basal condition and after a maximal

Table IV. Glucokinase Activity and Insulin Content in Pancreatic Islets of Different Rodent Models of Diabetes and Obese

\begin{tabular}{|c|c|c|c|c|c|}
\hline \multirow{3}{*}{ Rodents } & \multicolumn{3}{|c|}{ Islet glucokinase } & & \\
\hline & $V_{\max }$ & $V_{\max }$ & $K_{\mathrm{m}}$ & \multicolumn{2}{|c|}{ Islet insulin } \\
\hline & $\begin{array}{l}\text { mmol/kg dry } \\
\text { tissue per } h\end{array}$ & $\begin{array}{l}\text { mmol/liter intracellular } \\
\text { glucose space per } h\end{array}$ & $m M$ & ng/ug dry tissue & $\begin{array}{l}\text { g/liter intracellular } \\
\text { glucose space }\end{array}$ \\
\hline C57BL/KsJ mouse $(n=12)$ & $139.86 \pm 12.14$ & $49.07 \pm 4.26$ & $7.84 \pm 1.22$ & $212.60 \pm 9.06$ & $74.60 \pm 3.18$ \\
\hline$d b^{+} / d b^{+}$mouse $(n=6)$ & $184.07 \pm 22.67$ & $112.81 \pm 13.89^{\ddagger}$ & $10.73 \pm 1.77$ & $11.40 \pm 1.09^{\ddagger}$ & $6.99 \pm 0.67^{\ddagger}$ \\
\hline Sprague-Dawley rat $(n=4)$ & $125.77 \pm 10.42$ & $49.13 \pm 4.07$ & $10.51 \pm 1.21$ & $123.50 \pm 12.76$ & $48.24 \pm 4.98$ \\
\hline BHE rat $(n=4)$ & $96.94 \pm 5.35$ & $96.94 \pm 23.73$ & $12.40 \pm 2.08$ & $113.63 \pm 5.48$ & $107.19 \pm 5.17^{\ddagger}$ \\
\hline BHE rat on fat diet $(n=6)$ & $148.27 \pm 6.73$ & $92.67 \pm 4.21^{\ddagger}$ & $12.30 \pm 0.62$ & $115.73 \pm 7.86$ & $73.33 \pm 5.27^{*}$ \\
\hline Lean Zucker rat $(n=6)$ & $111.38 \pm 16.35$ & $52.78 \pm 7.75$ & $14.91 \pm 0.98$ & $93.59 \pm 9.86$ & $44.36 \pm 4.67$ \\
\hline Obese Zucker rat $(n=6)$ & $139.43 \pm 12.97$ & $74.17 \pm 6.90$ & $18.55 \pm 1.37^{*}$ & $71.30 \pm 10.83$ & $37.96 \pm 5.76$ \\
\hline
\end{tabular}

${ }^{*} P<0.05,{ }^{\ddagger} P<0.01$ compared with the relevant controls. 


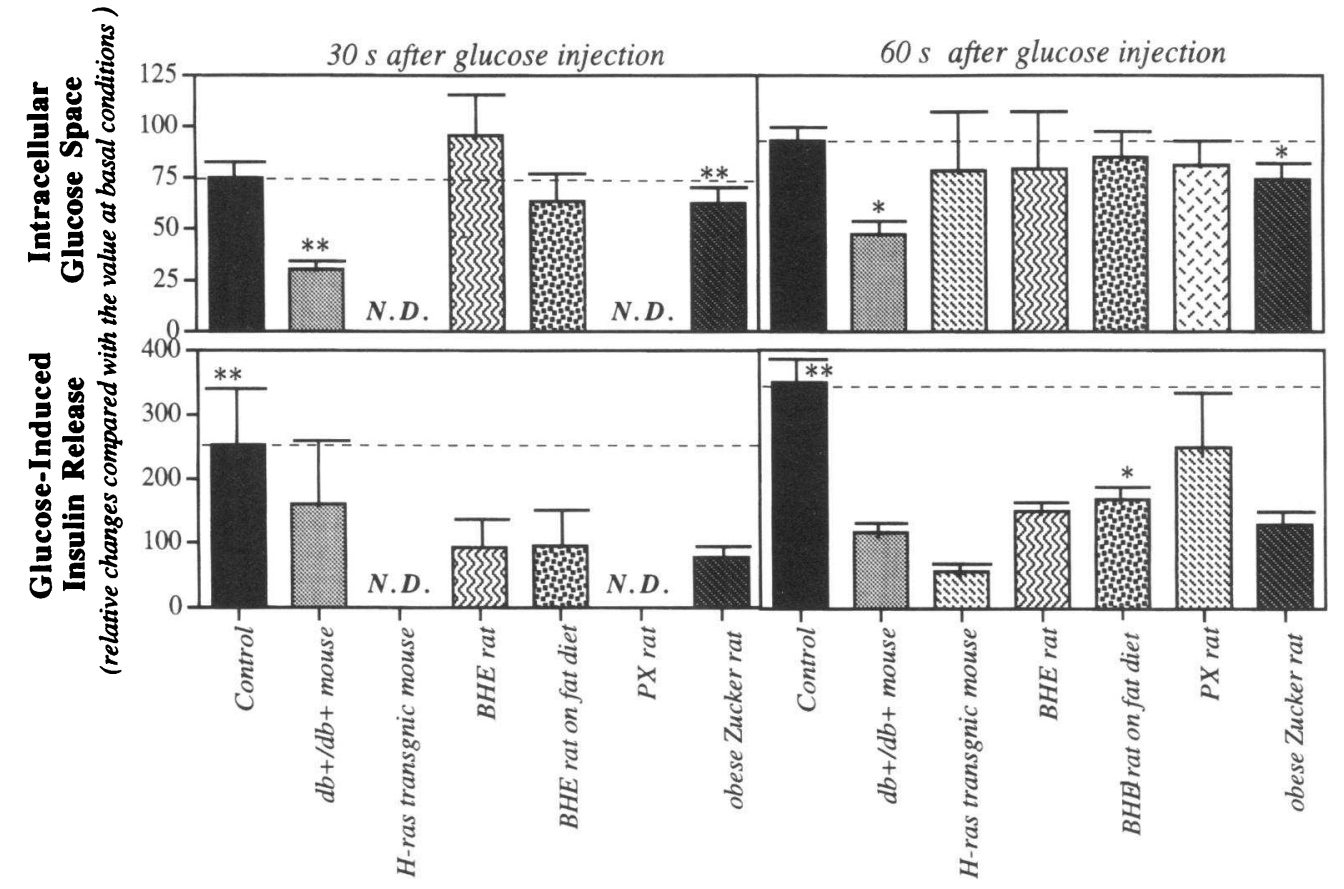

Figure 3. Summary of the relationship of islet in situ glucose uptake and glucose-induced insulin release in five animal models of diabetes or obesity and their relevant controls. Data are expressed in terms of relative changes of glucose uptake and insulin release at 30 and $60 \mathrm{~s}$ compared to the corresponding values at basal conditions. The control panels show the mean value of the relative changes in all four groups of control animals at 30 and 60 $\mathrm{s}$ compared to the corresponding value at basal condition. For actual individual values both in control groups and in diabetic or obese rodents, please see Tables I-III. ${ }^{*} P<0.05,{ }^{* *} P<0.01$ compared with the corresponding values at basal condition. ND, not determined. glucose load provides essential information not obtainable by other methodology. The determination of glucokinase activity by a quantitative radiometric oil well method applied here provides a measure of $\beta$ cell glucose metabolism, since this enzyme is an important determinant of glucose metabolism.

This approach provides unambiguous results when applied to normal islet tissue. The finding of an intracellular glucose space of 2-3 liter / kg dry tissue both under basal conditions and $60 \mathrm{~s}$ after a maximal glucose load in C57BL/ KsJ control and RIP-cHras mice, normal Sprague-Dawley rats, BHE rats at 50 $\mathrm{d}$ of age, sham-PX and PX rats, as well as lean and obese Zucker rats (Tables II and III) documents clearly $(a)$ that plasma glucose and $\beta$-cell intracellular glucose are virtually equal under basal conditions, and $(b)$ that the capacity for glucose transport is very high and almost certainly not rate limiting for islet glucose metabolism.

However, the interpretation of the results from some of these diabetic animals is less straightforward. The difficulties arise from the pathological alterations of the microscopic structure of pancreatic islets, most importantly of the increased fibrosis or the loss of $\beta$ cells that characterizes some of those models (i.e., the $\mathrm{BHE} / \mathrm{cdb}$ rat and the $d b^{+} / d b^{+}$mouse). It is known that $d b^{+} / d b^{+}$mice have a reduced $\beta$-cell mass at $18 \mathrm{wk}$ of age $(29,30)$. Therefore it is reasonable to interpret the finding of a reduced intracellular glucose space under basal conditions ( $1.63 \pm 0.3$ vs. $2.85 \pm 0.2$ liter $/ \mathrm{kg}$ dry tissue $)$ as an expression of $\beta$ cell loss. An analogous situation exists in the case of the $\mathrm{BHE} / \mathrm{cdb}$ rats. Islets of $\mathrm{BHE} / \mathrm{cdb}$ rats show a doubling of the inulin space compared to islets from all other animals. The most plausible explanation is a pathological expansion of the extracellular space by fibrosis, that is observed in preliminary microscopic studies (Fig. 2). Based on this observation, we assume that under basal conditions, the intra- and extracellular glucose are equal in $\beta$ cells of these rats, and that glucose transport is not impaired in $\beta$ cells of the fibrotic islets. The intracellular glucose space of $\sim 1$ liter $/ \mathrm{kg}$ dry tissue was maintained at 30 and $60 \mathrm{~s}$, even though the total islet glucose content rose four- to fivefold as a result of the maximal glucose load. This is best explained if it is assumed that glucose transport is highly effective. Considering the above interpretation it seemed justifiable to express the results of islet glucokinase measurements on the basis of intracellular glucose space. On this basis, islet glucokinase activity appears to be substantially increased in animals with severe diabetes (in $d b^{+} / d b^{+}$mice and $\mathrm{BHE} / \mathrm{cdb}$ rats on a high fat diet), and marginally so in obese Zucker rats. These results are comparable to those obtained from islet tissue from diabetic Chinese hamsters (31) and are consistent with results obtained from islets of streptozotocin diabetic rats (32). Diabetes might also lead to a relative increase of the mass of $\alpha$ cells, shown to be free of glucokinase in the normal animal (33). Such an event would strengthen the argument suggesting an increased glucokinase activity in $\beta$ cells in diabetes $(31,32)$.

The basal plasma glucose levels of control animals were $\sim 10 \mathrm{mM}$, even though most of the animals were overnight fasted. This level is more elevated than expected and might be due to the effects of anesthesia and surgical preparation of the animals. We have observed that in PX and sham PX rats, the plasma glucose level increased from $8.71 \pm 0.56 \mathrm{mM}$ before surgery to $11.93 \pm 0.83 \mathrm{mM}$ after anesthesia and surgery.

\section{Some characteristics of the animal models with diabetes or obesity}

(a) The C57BL/KsJ- $d b^{+} / d b^{+}$mouse is an animal model of diabetes with obesity. The syndrome shows early obesity and increased levels of plasma insulin, followed shortly by hyperglycemia and glycosuria (34). At later stages, plasma insulin falls, and weight loss occurs prior to death at 5-7 mo. The $\mathrm{db}^{+} / \mathrm{db} b^{+}$ mice used in this study were 15 wk old. Besides hyperglycemia and moderate hyperinsulinemia, we also found an extremely low content of insulin in islet tissue and a reduced intracellular glucose space. However, the islet extracellular space was normal. This is consistent with the result of previous morphological studies, indicating $\beta$ cell degranulation and necrosis (29). After glucose injection, islet glucose uptake was significantly 
slower than in controls and could account for the delay of glucose-stimulated insulin release. In addition, the depletion of insulin stored in the islets almost certainly contributes to the lack of rapid response to glucose challenge. However, the basal intracellular glucose level of $\beta$ cells was probably supranormal as a result of hyperglycemia and could explain high glucokinase activity and elevated plasma insulin. The data indicate that under basal conditions, glucose usage is very high in $\beta$ cells of these diabetic mice.

(b) The RIP-cHras transgenic mouse expresses the H-ras gene under control of the rat insulin promoter and develops male $\beta$ cell degeneration and diabetes in males. Hyperglycemia appears around 5 mo of age (35). The RIP-cHras mice we used here were 8-9 wk of age. At this young age, the animals are still normoglycemic but the GLUT-2 in the islet was estimated to be reduced by about $90 \%$ (36). Our results also showed that the plasma glucose and insulin levels were still in the normal range. The basal intracellular glucose space was comparable to that of $\mathrm{C57BL} / \mathrm{KsJ}$ mice, and the islet glucose uptake rate was not significantly slower than that in the control. However, no increased insulin secretion was found up to $3 \mathrm{~min}$ after glucose challenge (data not shown). In addition, these mice did not show any high levels of fasting plasma insulin. It has been observed that when the pancreas from these transgenic mice were perfused with $6.6 \mathrm{mM}$ glucose, a high baseline of insulin release was observed; insulin release stimulated by $16.7 \mathrm{mM}$ glucose was even more pronounced than that in controls (35). The reason for this difference remains unclear. It might be due to the different experimental design, since pancreatic perfusion might eliminate the influence of hormones and other factors which could modify insulin release in situ (37-39).

(c) The BHE/cdb rat is a model for NIDDM without obesity. Previous studies have shown that these rats are characterized by an age related rise in serum lipids and a deterioration of glucose tolerance despite the rise in serum insulin levels in response to a glucose challenge $(40,41)$. When these animals are fed a high fat and sucrose diet, the diabetic syndrome becomes more severe (42). Here we showed that the fasting plasma glucose and insulin levels in these rats fed a high fat diet were significantly higher than those in the Sprague-Dawley rats, and that the i.v. glucose tolerance in these animals exhibited an abnormal blood glucose profile associated with a relatively high insulin release. The present study showed that $\mathrm{BHE} / \mathrm{cdb}$ rats at $50 \mathrm{~d}$ of age had a normal islet intracellular glucose space, while the older BHE/cdb rats (fed either a stock diet or a high fat diet) had a reduced islet intracellular glucose space, which might be due to fibrotic changes. The islet glucose uptake rate appeared to be normal, and glucokinase seemed to be enhanced in these two groups of older BHE rats. This impaired insulin secretion in response to glucose is thus probably not due to reduced $\beta$ cell glucose metabolism.

(d) The partially pancreatectomized rat becomes moderately diabetic following surgery that removes $90 \%$ of the pancreas, and is characterized by hyperglycemia, hypoinsulinemia and a blunted or absent insulin release response after glucose challenge (22). However, the islet intracellular glucose space and the glucose uptake rate after glucose injection were not different from those in sham-PX rats suggesting that glucose usage is normal.

(e) The obese Zucker rats who inherit obesity as an autosomal recessive trait are obese and hyperinsulinemic, but are relatively normoglycemic or show only slightly elevated blood su- gar (43). We found in our group of obese Zucker rats that glucose uptake rates were reduced and that the insulin release response to glucose stimulation was diminished or absent. The glucokinase activity in these animals was marginally increased to $140 \%$, probably due to the mild hyperglycemia. The reduced glucose uptake rate could account for the delayed insulin release after glucose stimulation.

\section{Relationship of islet in situ glucose uptake, glucokinase activity and glucose-induced insulin release}

Under basal conditions, the intracellular islet glucose space in five models of diabetes or obesity was either indistinguishable from controls or reduced. Even though in the $\mathrm{db}^{+} / \mathrm{db} b^{+}$mice the intracellular glucose space was reduced, there was probably ample glucose in the islet tissue to fuel the metabolism under steady-state conditions. In fact, the data suggest that intra- and extracellular glucose concentrations are equal under basal conditions. The hypoinsulinemia in the PX rat can therefore not be attributed to insufficient glucose supply to $\beta$ cells. Similarly in the RIP-cHras transgenic mice, the reported reduction of $\beta$ cell GLUT 2 to $10 \%$ of controls did not limit glucose access to $\beta$ cells nor basal insulin release. Glucose transport can thus be discounted as the determining factor of glucose metabolism and insulin release under basal steady-state conditions. Glucose transport could, however, become rate limiting in transition states on a minute-to-minute time scale. In the $d b^{+} / d b^{+}$ mice, the glucose uptake rate was significantly decreased at $60 \mathrm{~s}$ after a glucose load. Obese Zucker rats also exhibited a decrease of the glucose uptake rate, but the intracellular glucose reached nearly $75 \%$ of that at basal conditions $1 \mathrm{~min}$ after a glucose load. The functional transport defect is thus relatively small. The RIP-cHras mice (even though drastically compromised by a lack of GLUT2 [36]), BHE/cdb rats and PX rats showed normal glucose uptake rates. Glucose-induced insulin release in all five experimental groups was delayed or reduced. Impaired insulin release was therefore not correlated with impaired glucose uptake in these animals. However, it remains to be explored whether islet glucose in situ uptake is altered at time points of $<30 \mathrm{~s}$, or when the blood glucose level increases submaximally. The present data show that a connection between reduced glucose uptake and abnormal acute insulin release might exist only in the $d b^{+} / d b^{+}$mouse and obese Zucker rat.

Islet glucokinase activities in $d b^{+} / d b^{+}$mice, BHE rats (with or without a high fat diet) and obese Zucker rats were higher than in their relevant controls suggesting that glucokinase was induced by the elevated blood glucose and the correspondingly increased islet glucose. Previously we have observed that in normal rats, the activity of islet glucokinase was regulated by the ambient glucose concentration both in situ and organ culture $(12,13)$. The present results demonstrated $\beta$-cell glucokinase induction might also occur in diabetic and obese animals. A glucokinase defect can therefore be excluded as cause of diabetes in these animals.

In summary, our present study further elucidates the relationship of islet glucose uptake and glucose-induced insulin release in five animal models of diabetes or obesity. A dysfunction of GLUT-2 is of minor or no consequence for intracellular glucose availability under basal equilibrium conditions and is not the universal cause of impaired insulin release in these animals. A defect of islet glucokinase is also excluded as cause of the pathology in $d b^{+} / d b^{+}$mice, in BHE rats and in obese 
Zucker rats. The cause of the $\beta$ cell's inability to respond to glucose stimulation might be located at later steps of glucose metabolism, in the metabolic coupling processes that connect glucose metabolism to secretion, or in the secretion mechanism itself.

\section{Acknowledgments}

This work was supported by grants from the NIH DK-19525 and DK22122 (FMM), an ADA Research Award and JDF Career Development Award (YL), NIH DK-35449 and DK-36836 (SBW), and a Research Grant from the JDF (SE).

\section{References}

1. Thorens, B., H. K. Sarkar, H. R. Kaback, and H. F. Lodish. 1988. Cloning and functional expression in bacteria of a novel glucose transporter present in liver, intestine, kidney, and beta-pancreatic islet cells. Cell. 55:281-290.

2. Orci, L., B. Thorens, M. Ravazzola, and H. F. Lodish. 1989. Localization of the pancreatic beta cell glucose transporter to specific plasma membrane domains. Science (Wash. DC). 245:295-297.

3. Burant, C. F., and G. I. Bell. 1992. Mammalian facilitative glucose transporters: evidence for similar substrate recognition sites in functionally monomeric proteins. Biochemistry. 31:10414-10420.

4. Johnson, J. H., C. B. Newgard, J. L. Milburn, H. F. Lodish, and B. Thorens. 1990. The high $\mathrm{Km}$ glucose transporter of islets of Langerhans is functionally similar to the low affinity transporter of liver and has an identical primary sequence. J. Biol. Chem. 265:6548-6551.

5. Johnson, J. H., A. Ogawa, L. Chen, L. Orci, C. B. Newgard, T. Alam, and R. H. Unger. 1990. Underexpression of beta cell high $K_{\mathrm{m}}$ glucose transporters in noninsulin-dependent diabetes. Science (Wash. DC). 250:546-549.

6. Johnson, J. H., B. P. Crider, K. McCorkle, M. Alford, and R. H. Unger. 1990. Inhibition of glucose transport into rat islet cells by immunoglobulins from patients with new-onset insulin-dependent diabetes mellitus. N. Engl. J. Med. 322:653-659.

7. Inman, L. R., C. T. McAllister, L. Chen, S. Hughes, C. B. Newgard, J. R. Kettman, R. H. Unger, and J. H. Johnson. 1993. Autoantibodies to the GLUT-2 glucose transporter of beta-cells in insulin-dependent diabetes-mellitus of recent onset. Proc. Natl. Acad. Sci. USA. 90:1281-1284.

8. Unger, R. H. 1991. Diabetic hyperglycemia: link to impaired glucose transport in pancreatic beta-cells. Science (Wash. DC). 251:1200-1205.

9. Matschinsky, F. M., and J. E. Ellerman. 1968. Metabolism of glucose in the islets of Langerhans. J. Biol. Chem. 243:2730-2736.

10. Meglasson, M. D., and F. M. Matschinsky. 1986. Pancreatic islet glucose metabolism and regulation of insulin secretion. Diabetes Metab. Rev. 2:163-214.

11. Magnuson, M. A. 1992. Tissue-specific regulation of glucokinase gene expression. J. Cell. Biochem. 48:115-121.

12. Bedoya, F. J., F. M. Matschinsky, T. Shimizu, J. J. O’Neil, and M. C. Appel. 1986. Differential regulation of glucokinase activity in pancreatic islets and liver of the rat. J. Biol. Chem. 261:10760-10764.

13. Liang, Y., H. Najafi, R. M. Smith, E. C. Zimmerman, M. A. Magnuson, M. Tal, and F. M. Matschinsky. 1992. Concordant glucose induction of glucokinase, glucose usage, and glucose-stimulated insulin release in pancreatic islets maintained in organ culture. Diabetes. 41:792-806.

14. Froguel, P., H. Zouali, N. Vionnet, G. Velho, M. Vaxillaire, F. Sun, S. Lesage, M. Stoffel, J. Takeda, and P. Passa. 1993. Familial hyperglycemia due to mutations in glucokinase. Definition of a subtype of diabetes mellitus. $N$. Engl. J. Med. 328:697-702.

15. Gidh-Jain, M., J. Takeda, L. Z. Xu, A. J. Lange, N. Vionnet, M. Stoffel, P. Froguel, G. Velho, F. Sun, D. Cohen, et al. 1993. Glucokinase mutations associated with non-insulin-dependent (type 2) diabetes mellitus have decreased enzymatic activity: Implications for structure/function relationships. Proc. Natl. Acad. Sci. USA. 90:1932-1936.

16. Matschinsky, F. M. 1990. Glucokinase as glucose sensor and metabolic signal generator in pancreatic beta-cells and hepatocytes. Diabetes. 39:647-652.

17. Lowry, O. H. 1953. The quantitative histochemistry of the brain, histological sampling. J. Histchem. Cytochem. 1:420-428.

18. Matschinsky, F. M., J. E. Ellerman, R. Landgraf, J. Krzanowski, J. KotlerBrajtburg, and R. Fertel. 1971. Quantitative histochemistry of glucose metabolism in the islets of Langerhans. In Recent Advances in Quantitative Histo- and
Cytochemistry. Volume 3. Methods and Applications, U. C. Dubach, U. E. Schmidt, editors. Hans Huber, Berne, Switzerland. 143-182.

19. Bedoya, F. J., J. M. Wilson, A. K. Ghosh, D. Finegold, and F. M. Matschinsky. 1986. The glucokinase glucose sensor in human pancreatic islet tissue Diabetes. 35:61-67.

20. Lowry, O. H., and J. V. Passonneau. 1972. A collection of metabolite assays. In A Flexible System of Enzymatic AnalysisLowry. O. H. Lowry and J. V. Passonneau, editors. Academic Press, Inc., New York. 147-220.

21. Herbert, V., K. S. Lau, C. W. Gottlieb, and S. Bleicher. 1965. Coated charcoal immunoassay of insulin. J. Clin. Endocrinol. Metab. 25:1375-1384.

22. Bonner-Weir, S., D. F. Trent, and G. C. Weir. 1983. Partial pancreatectomy in the rat and subsequent defect in glucose-induced insulin release. J. Clin. Invest. 71:1544-1553.

23. Lowry, O. H., and J. V. Passonneau. 1972. The quartz fiber fishpole balance. In A Flexible System of Enzymatic AnalysisLowry. O. H. Lowry and J. V. Passonneau, editors. Academic Press, Inc., New York. 237-249.

24. Bedoya, F. J., M. D. Meglasson, J. M. Wilson, and F. M. Matschinsky. 1985. Radiometric oil well assay for glucokinase in microscopic structures. Anal. Biochem. 144:504-513.

25. Salas, J., M. Salas, E. Vinuela, and A. Sols. 1965. Glucokinase of rabbit liver: purification and properties. J. Biol. Chem. 240:1014-1018.

26. Burch, P. T., D. K. Berner, A. Leontire, A. Vogin, B. M. Matschinsky, and F. M. Matschinsky. 1984. Metabolic adaption of pancreatic islet tissue in aging rats. J. Gerontol. 39:2-6.

27. Meglasson, M. D., P. T. Burch, D. K. Berner, H. Najaf, A. P. Vogin, and F. M. Matschinsky. 1983. Chromatographic resolution and kinetic characterization of glucokinase from islets of Langerhans. Proc. Natl. Acad. Sci. USA. 80:8589.

28. Trus, M. D., W. S. Zawalich, P. T. Burch, D. K. Berner, V. A. Weill, and F. M. Matschinsky. 1981. Regulation of glucose metabolism in pancreatic islets. Diabetes. 30:911-922.

29. Like, A. A., and W. L. Chick. 1970. Studies in the diabetic mutant mouse: I. Light microscopy and radioautography of pancreatic islets. Diabetologia. 6:207-215.

30. Like, A. A. 1985. Spontaneous diabetes in animals. In The Diabetic Pancreas. B. W. Volk and E. R. Arquilla, editors. Plenum Medical Book Co., New York. 385-413.

31. Matschinsky, F. M., M. D. Meglasson, P. T. Burch, D. K. Berner, H. Najafi, A. P. Vogin, D. Garfinkel, and L. Garfinkel. 1983. Glucokinase (ATP: D-glucose 6-phosphotransferase E.C.2.7.1.2), the glucose sensor of pancreatic islet $\beta$-cells. In Proceedings of the 13th Congress of the International Diabetes Federation. E. Mngola, editor. Excerpta Medica, Amsterdam 337-344.

32. Bedoya, F. J., J. C. Oberholtzer, and F. M. Matschinsky. 1987. Glucokinase in B-cell-depleted islets of Langerhans. J. Histochem. Cytochem. 35:10891093.

33. Jetton, T. L., and M. A. Magnuson. 1992. Heterogeneous expression of glucokinase among pancreatic beta-cells. Proc. Natl. Acad. Sci. USA. 89:26192623.

34. Coleman, D. L., and K. P. Hummel. 1967. Studies with the mutation, diabetes, in the mouse. Diabetologia. 3:238-248.

35. Efrat, S., N. Fleischer, and D. Hanahan. 1990. Diabetes induced in male transgenic mice by expression of human H-ras oncoprotein in pancreatic beta cells. Mol. Cell. Biol. 10:1779-1783.

36. Tal, M., Y. J. Wu, M. Leiser, M. Surana, H. Lodish, N. Fleischer, G. Weir, and S. Efrat. 1992. [ Val12] HRAS downregulates GLUT2 in beta cells of transgenic mice without affecting glucose homeostasis. Proc. Natl. Acad. Sci. USA. 89:5744-5748.

37. Willingham, M. C., I. Pastan, T. Y. Shih, and E. M. Scolnick. 1980. Localization of the Harvey strain of murine sarcoma virus to plasma membrane of transformed cells by electron microscopic immunocytochemistry. Cell. 19:1005-1014.

38. Robertson, R. P., E. R. Seaquist, and T. F. Walseth. 1991. G proteins and modulation of insulin secretion. Diabetes. 40:1-6.

39. Seaquist, E. R., A. R. Neal, K. D. Shoger, T. F. Walseth, and R. P. Robertson. 1992. G-proteins and hormonal inhibition of insulin secretion from HIT-T15 cells and isolated rat islets. Diabetes. 41:1390-1399.

40. Berdanier, C. D. 1991. The Cdb:BHE rat-A model for non-insulin-dependent, nonobese diabetes mellitus. ILAR News. 33:58-62.

41. Berdanier, C. D. 1991. The BHE rat: an animal model for the study of non-insulin-dependent diabetes mellitus. FASEB J. 5:2139-2144.

42. Bue, J. M., D. B. Hausman, and C. D. Berdanier. 1989. Gestational diabetes in the BHE rat: Influence of dietary fat. Am. J. Obstet. Gynecol. 161:234 240.

43. Kurtz, T. W., R. C. Morris, and H. A. Pershadsingh. 1989. The Zucker fatty rat as a genetic model of obesity and hypertension. Hypertension (Dallas). 13:896-901. 